\title{
Implementasi Kebijakan Keterbukaan Informasi Publik pada Dinas Kominfo Kota Tasikmalaya
}

\author{
Tiara Indah \\ Prodi Ilmu Komunikasi Universitas Islam Indonesia, Yogyakarta \\ indahtiara2@gmail.com \\ Puji Hariyanti \\ Prodi Ilmu Komunikasi Universitas Islam Indonesia, Yogyakarta \\ puji.hariyanti@uii.ac.id
}

\begin{abstract}
Abstrak
Penelitian ini mengkaji bagaimana implementasi kebijakan keterbukaan informasi publik yang dijalankan oleh Dinas Komunikas dan Informatika Pemerintahan Kota Tasikmalaya. Penelitian ini dilakukan dengan menggunakan metode deskriptif kualitatif, dengan pengambilan data melalui wawancara dan observasi langsung baik di kantor Dinas Kominfo Kota Tasikmalaya maupun pada media sosial yang digunakan oleh petugas dalam menyebarluaskan informasi publik. Hasil yang diperoleh adalah faktor-faktor yang dapat mempengaruhi keberhasilan implementasi kebijakan yaitu Faktor Komunikasi, Sumber Daya, Disposisi dan Struktur Birokrasi sudah cukup terpenuhi dengan baik, hanya saja terdapat kendala pada faktor sumber daya yaitu kurangnya jumlah staf seksi pelayanan informasi publik yang merupakan implementor dalam kebijakan tersebut, selain itu belum terpenuhinya fasilitas penunjang seperti kamera profesional. Meskipun jumlah staf yang kurang memadai, implementor memiliki keahlian dalam menjalankan kebijakan tersebut yaitu mampu mengoperasikan website dan juga media sosial sebagai sarana menyebarluaskan informasi publik. Hal tersebut menjadi salah satu penunjang keberhasilan implementasi kebijakan yang dijalankan sehingga pada November 2017 Dinas Kominfo Kota Tasikmalaya mendapatkan penghargaan ke-3 pada Anugerah Media Humas 2017 kategori media sosial.
\end{abstract}

Kata kunci: Impelentasi Kebijakan, Keterbukaan Informasi Publik, Pemerintahan kota Tasikmalaya

\begin{abstract}
This study examined the implementation of public information disclosure policies carried out by the Office of Communications and Information Technology of Tasikmalaya. This research was conducted with a qualitative descriptive method. The data were taken through interviews and direct observation at the office and also on social media. This study found that the factors for successful policy implementation; ie Communication, Resource, Disposition and Bureaucratic Structure Factors are quite well fulfilled, while there are some problems; ie the lack of the number of public information service staff as the implementors of policy and of supporting facilities such as a professional camera. Despite the insufficient number of staff, the implementor able to operate the website as well as social media as a means of disseminating public information. This became one of the keys of the successful implementation of the policy so that Tasikmalaya City Communications Department rewarded as 3 rd best social media category in Media Public Relation Award November 2017.
\end{abstract}

Keywords: Policy Implementation, Public Information, The Government city of 


\section{PENDAHULUAN}

Keterbukaan informasi publik merupakan salah satu pilar kebebasan berekspresi serta pilar demokrasi, transparansi dan good governance. Dalam undang-undang tersebut, hak masyarakat untuk mendapatkan informasi mendapatkan jaminan, dan implementasi kebijakan keterbukaan informasi publik menjadi salah satu upaya pemenuhan hak asasi manusia (HAM). Selain itu, dengan adanya keterbukaan informasi publik, masyarakat dapat memantau lajunya kinerja pemerintahan. Oleh karena itu, setiap lembaga Badan Publik harus menyediakan petugas bagi pelayanan masyarakat di bidang informasi. Petugas Komunikasi dan Informatika ini baik dalam tingkat nasional, provinsi ataupun daerah memiliki tugas pokok yang diatur oleh Undang-Undang No 14/2008 terkait Keterbukaan Informasi Publik. Melalui undang-undang, setiap badan publik memiliki kewajiban untuk menjalankan kebijakan KIP agar tujuan undang-undang tersebut dapat tercapai.

Terwujudnya pemerintahan terbuka menjadi salah satu ciri dari good governance atau pemerintahan yang baik. Suatu pemerintahan dapat dikatakan telah melaksanakan prinsip-prinsip good governance apabila dalam penyelenggaraan pemerintahan terdapat manajemen pemerintahan yang solid dan bertanggung jawab serta memiliki prinsip yang sejalan dengan konsep demokrasi (Sedarmayanti, 2004: 22). Ada dua orientasi dalam kepemerintahan yang baik. Pertama, orientasi negara harus mengarah pada pencapaian tujuan nasional. Kedua, pemerintah harus memiliki fungsi yang ideal seperti bekerja secara efektif dan efisien untuk mengupayakan tujuan nasional (Sedarmayanti, 2004: 42).

Pemerintahan Kota Tasikmalaya sebagai badan publik juga memiliki kewajiban dalam memenuhi kebutuhan informasi publik pada masyarakatnya. Ini telah dilaksanakan oleh pemerintah Kota Taksimalaya, dan, pada 2015, Dinas Perhubungan dan Komunikasi dan Informatika (DISHUBKOMINFO) mendapatkan penghargaan dalam acara Kominfo Award sebagai juara ke-3 dari 27 pemerintahan kota dan kabupaten di Jawa Barat dalam kategori badan publik yang menerapkan keterbukaan informasi publik terlengkap sesuai dengan peraturan perundang-undangan KIP. Ini menunjukkan bahwa Kota Tasikmalaya bersungguh-sungguh dalam melaksanakan undang-undang keterbukaan informasi publik.

Pada 2017, Dinas Perhubungan dan Dinas Kominfo Kota Tasikmalaya dibagi menjadi dua dinas yang berbeda. Tugas untuk mengimplementasikan kebijakan keterbukaan informasi publik dilakukan oleh Dinas Kominfo. Di Dinas Kominfo Kota Tasikmalaya ini, keterbukaan informasi publik dikelola oleh Seksi Pelayanan Informasi Publik. Sebagai dinas baru, petugas harus merancang hal-hal yang berkaitan dengan tugas pokoknya. Salah satunya adalah menyebarluaskan informasi publik yang termasuk dalam implementasi kebijakan keterbukaan informasi publik.

Penelitian ini ingin mengkaji bagaimana implementasi kebijakan keterbukaan publik yang telah dilakukan oleh Dinas Kominfo pemerintahan Kota Tasikmalaya, khususnya pada pelayanan informasi publik. Penelitian ini juga mengkaji faktor-faktor pendukung dan penghambat Diskominfo pemerintahan 
Kota Tasikmalaya dalam implementasi kebijakan keterbukaan informasi publik, mengingat Dinas Kominfo merupakan Dinas yang baru berdiri pada 2017.

Beberapa penelitian tentang keterbukaan informasi publik telah dilakukan. Salah satunya dilakukan oleh Agus Setiaman, Dadang Sugiana dan Jimi Narotama M (2013). Penelitian dilakukan di Kota Bandung. Pertanyaan penelitian yang diajukan dalam penelitian tersebut adalah bagaimana bentuk informasi yang disediakan oleh Pemerintahan Kota Bandung dalam mengimplementasikan keterbukaan informasi publik kepada masyarakatnya, dan juga bagaimana pemerintahan Kota Bandung mengoptimalkan sumber daya dalam implementasi keterbukaan informasi publik?

Penelitian tersebut menemukan bahwa sebagian besar masyarakat Kota Bandung tidak memahami keterbukaan informasi publik. Ini karena pada dasarnya masyarakat tidak memahami informasi publik. Salah satu contoh kurangnya pemahaman masyarakat terhadap hal tersebut adalah sebagian masyarakat kota Bandung mengetahui bahwa setiap ada pembangunan sarana publik maka selalu tersedia pengumuman tentang batas waktu, pengerjaan, biaya dan sebagainya. Namun, masyarakat tidak mengetahui bahwa hal tersebut merupakan upaya implementasi keterbukaan informasi publik. Ini dapat terjadi karena kurangnya sosialisasi yang dilakukan oleh pemerimtaham Kota Bandung terkait dengan keterbukaan informasi publik.

Khairunnisa Kamilah (2015) juga melakukan penelitian tentang keterbukaan informasi publik. Tujuan penelitian yang dilakukan

Kamilah adalah mendeskripsikan dan menganalisis bagaimana peranan yang dilakukan oleh Bappeda dalam upaya mengimplementasikan kebijakan UU KIP di Kota Samarinda. Teknik pengumpulan data dilakukan dengan menggunakan teknik purposive sampling dan snowball sampling. Analisis dilakukan secara deskriptif dengan tujuan untuk memberikan gambaran serta penjelasan tentang variabel yang diteliti.

Hasil yang diperoleh penelitian ini bahwa keterbukaan informasi publik yang dijalankan oleh Bappeda dengan adanya layanan akses berupa informasi wajib, dan disediakan secara berkala seperti informasi mengenai Rencana Pembangunan Jangka Menengah, (RPJM), Rencana Pembangunan Jangka Panjang (RPJP) serta informasi yang wajib diadakan setiap saat, yaitu berkaitan dengan data-data terkait pembangunan, evaluasi, dan pengendalian. Dikarenakan website resmi Bappeda (bappeda.samarindakota.go.id) sedang dalam masa perbaikan, jika masyarakat Kota Samarinda ingin mengetahui informasi terkait dengan pembangunan daerah, dapat secara langsung datang ke Kantor Bappeda untuk melihat dokumen yang bahkan bisa dicopi dan disimpan dalam bentuk soft file. (Kamiliah, 2015: 10-11).

Penelitian yang menghubungkan implementasi kebijakan publik dengan good governance dilakukan oleh Prabowo (2014). Penelitian dilakukan di tiga badan publik, yakni Bappeda, DPKAD, dan Dinas Pendidikan Kota Semarang. Penelitian menggunakan metode kualitatif.

Penelitian ini mampu menjelaskan bahwa pelaksanaan Undang-Undang Keterbukaan Publik tidak berjalan dengan efektif. Dari ketiga badan publik yang 
menjadi objek penelitian ini, Dinas Pendidikan merupakan Badan Publik yang paling lengkap dalam penyajian informasi publik dibandingkan dengan BAPPEDA dan DPKAD. Kurang efektifnya pelaksanaan kebijakan keterbukaan informasi publik dilandaskan oleh kurang maksimalnya sosialisasi terkait implementasi UU tersebut oleh Humas Pemerintahan Kota Semarang sehingga petugas terkait kurang memahami bagaimana pelaksanaan dari kebijakan keterbukaan informasi tersebut. Selain itu, keterbatasan personil dan anggaran juga menjadi alasan lain mengapa pelaksanaan UU KIP tersebut belum berjalan secara maksimal (Prabowo, 2014: 26-29).

Sebagai suatu kebijakan publik, implementasi undang-undang keterbukaan informasi publik haruslah dilakukan dengan tepat. Ini karena implementasi mencakup beragam tindakan, yakni mengumpulkan data, mendistribusikan informasi, menganalisis berbagai masalah, mengalokasikan dan merekrut personalia, merencanakan atas masa depan dan lain-lain (Edwards, 2003: 1-2). Dalam implementasi kebijakan, terdapat beberapa hal penting yang harus diperhatikan, yaitu Komunikasi, Sumber Daya, Disposisi dan Struktur Birokrasi. Menurut Edward III (seperi dikutip Awang, 2010: 44), keempat faktor tersebut dapat menentukan keberhasilan dalam implementasi suatu kebijakan.

Faktor pertama komunikasi. Para pembuat kebijakan harus mengkomunikasikan kebijkannya dengan jelas, akurat dan konsisten kepada para implementor agar para implementor mengetahui apa saja yang harus dilakukan dalam implementasi kebijakan tersebut. Menurut Edaward III (seperti dikutip Awang, 2010: 42), komunikasi dalam implementasi kebijakan harus terjadi transmisi atau meneruskan informasi dengan jelas dan juga konsisten. Dalam kebijakan keterbukaan informasi publik, komunikasi tidak hanya terjadi dalam internal implementor saja karena implementor juga harus mengkomunikasikan informasi kepada masyarakat sebagai publiknya.

Faktor Kedua sumber daya. Sumber daya meliputi jumlah staf yang cukup untuk menjalankan suatu kebijakan, tetapi jumlah staf yang cukup apabila tidak memiliki keahlian yang diperlukan akan menjadi sia-sia. Untuk itu, staf juga harus memiliki keahlian sesuai dengan yang dibutuhkan untuk mengimplementasikan suatu kebijakan. Ini karena apabila implementasi kebijakan dijalankan oleh orang-orang yang tidak ahli dalam tugasnya maka implementasi kebijakan tersebut akan berjalan tidak efektif (Awang, 2010: 42). Sumber daya lain yang penting dalam sebuah implementasi kebijakan adalah fasilitas yang menunjang seperti bangunan, peralatan, yang memadai. Kurangnya sumber daya tentu akan menghambat implementasi kebijakan yang akan atau sedang dijalankan. (Awang, 2010: 42).

Faktor ketiga, Disposisi atau sikap implementor. Ini merupakan hal penting lainnya dalam implementasi kebijakan karena para implementor bukan hanya harus mengetahui dan memahami apa yang harus dikerjakan, melainkan juga harus memiliki kehendak untuk melakukan suatu kebijakan. Menurut Edward III (dalam Awang, 2010: 43), disposisi dalam implementasi kebijakan memiliki arti sebagai kecenderungan, keinginan atau kesepakatan para implementor untuk melaksanakan suatu kebijakan dalam upaya menjalankan 
implementasi kebijakan yang baik. Disposisi juga merupakan watak dan karakteristik yang dimiliki oleh para implementor yang berwujud dalam sikap memiliki komitmen, kejujuran dan juga sikap demokratis. Implementor yang menjalankan disposisi yang baik memiliki kemungkinan lebih besar untuk menjalankan kebijakan sesuai dengan yang diinginkan oleh pembuat kebijakan (Subarsono, 2013: 92).

Faktor keempat struktur birokrasi. Birokrasi merupakan sistem yang dijalankan oleh badan publik ataupun pemerintahan sesuai dengan pola kerja dan tata nilai yang berlaku dan dijalankan secara hirarkis serta berjenjang sesuai dengan tugas pokok dan fungsi yang sudah menjadi tanggung jawabnya dalam sebuah jabatan (Awang, 2010: 178). Dengan adanya struktur birokrasi yang jelas, segala sesuatunya akan lebih terperinci seperti pengembangan prosedur standar pengoprasian (standard operating procedure) atau SOP yang dirancang untuk kebijaka-kebijakan masa depan. Menurut Edward II (seperti dikutip Awang, 2010: 43), selain SOP, dalam faktor ini juga terdapat fragmentasi yang berasal dari tekanan-tekanan di luar unit-unit birokrasi. Untuk itu, sebaiknya, badan publik memang melakukan koordinasi dengan badan publik lainnya ataupun dengan pihak eksternal.

$$
\text { Hadirnya undang-undang }
$$

keterbukaan informasi publik memudahkan setiap individu atau kelompok dalam suatu wilayah atau daerah untuk mengakses setiap informasi yang dibutuhkannya. Adanya kemudahan tersebut akan menjadi keuntungan tersendiri bagi rakyat. Dengan demikian, konsep demokrasi yang dianut oleh Indonesia yang menitikberatkan pada rakyat, yakni dari rakyat oleh rakyat oleh rakyat dapat tercapai.

Ada beberapa tujuan UndangUndang Keterbukaan informasi publik (Sastro, dkk., 2010: 4-5). Pertama, menjamin hak masyarakat mengetahui apa saja yang dilakukan oleh badan publik dari mulai perencanaa program kebijakan publik, pelaksanaan kebijakan publik hingga pengambilan keputusan publik. Kedua, mendorong masyarakat untuk ikut berpartisipasi dalam pengambilan keputusan yang dilakukan oleh badan publik. Ketiga, meningkatkan peran aktif masyarakat dalam pengelolaan badan publik yang baik sehingga adanya transparansi, efektif dan efisien, akuntabel serta dapat dipertanggungjawabkan. Keempat, agar publik mengetahui alasan diambilnya suatu kebijakan publik tertentu yang mempengaruhi orang banyak. Kelima, dapat mengembangkan ilmu pengetahuan serta ikut berupaya mencerdaskan kehidupan bangsa. Keenam, menjadi acuan bagi badan publik dalam melaksankan pelayanan informasi publik sehingga menghasilkan pelayanan informasi publik yang berkualitas.

\section{METODE PENELITIAN}

Penelitian ini menggunakan metode penelitian kualitatif. Menurut Bodan dan Taylor (seperti dikutip Moleong, 2010: 4), penelitian kualitatif adalah penelitian yang menghasilkan data secara desktriptif berupa kata-kata tertulis maupun lisan dari orang-orang dan perilaku yang dapat diamati. Selain itu, penelitian kualitatf juga merupakan penelitian yang memiliki tujuan agar peneliti nantinya dapat memahami fenomena tentang apa yang dialami oleh subjek penelitian seperti perilaku, presepsi, motivasi, tindakan, dan lain-lain. 
Pengumpulan data dilakukan melalui wawancara, yakni teknik tanya jawab dengan narasumber baik secara langsung maupun melalui perantara guna membicarakan berbagai macam persoalan terkait dengan implemetasi kebijakan keterbukaan informasi publik yang telah dilakukan oleh Diskominfo pemerintahan
Kota Tasikmalaya. Dalam penelitian ini, peneliti melakukan wawancara dengan implementor kebijakan KIP, dan juga beberapa orang masyarakat kota Tasikmalaya.

Tabel 1

Informan Penelitian

\begin{tabular}{|l|l|l|l|l|}
\hline No & Nama & Asal & $\begin{array}{l}\text { Jadwal } \\
\text { Wawancara }\end{array}$ & Pekerjaan \\
\hline $\mathbf{1}$ & $\begin{array}{l}\text { Agast } \\
\text { Laksamana, SE }\end{array}$ & $\begin{array}{l}\text { Kota } \\
\text { Tasikmalaya }\end{array}$ & $\begin{array}{l}\text { 7 Desember } \\
2017\end{array}$ & $\begin{array}{l}\text { Ketua Seksi Pelayanan } \\
\text { Informasi Publik }\end{array}$ \\
\hline $\mathbf{2}$ & Yaman Budiman & $\begin{array}{l}\text { Kota } \\
\text { Tasikmalaya }\end{array}$ & $\begin{array}{l}\text { 8 Desember } \\
2017\end{array}$ & Lurah Sukamaju Kaler \\
\hline 3 & Dedy Suryadi & $\begin{array}{l}\text { Kota } \\
\text { Tasikmalaya }\end{array}$ & $\begin{array}{l}\text { 8 Desember } \\
2017\end{array}$ & $\begin{array}{l}\text { Perangkat Kelurahan } \\
\text { Sukamaju Kaler }\end{array}$ \\
\hline 4 & Fadilah Fatimah & $\begin{array}{l}\text { Kota } \\
\text { Tasikmalaya }\end{array}$ & $\begin{array}{l}\text { 8 Desember } \\
\text { 2017 }\end{array}$ & Mahasiswi \\
\hline 5 & Diana Santika & $\begin{array}{l}\text { Kota } \\
\text { Tasikmalaya }\end{array}$ & $\begin{array}{l}\text { 8 Desember } \\
2017\end{array}$ & Mahasiswi \\
\hline
\end{tabular}

Peneliti juga melakukan pengamatan objek/subjek penelitian secara langsung (observasi) guna memperkaya data wawancara. Dalam pengamatan ini, peneliti melakukan pengamatan di kantor Dinas Kominfo, dan mengamati media yang digunakan dalam mengkomunikasikan informasi publik.

\section{HASIL DAN PEMBAHASAN}

Adanya undang-undang yang mengatur keterbukaan informasi publik mewajibkan seluruh badan publik untuk memenuhi kebutuhan informasi publik masyarakatnya. Sebagai badan publik, pemerintah Kota Tasikmalaya memiliki kewajiban untuk memenuhi kebutuhan informasi publik masyarakat Kota Tasikmalaya sesuai dengan UU KIP No
14/2008 yang dijadikan sebagai pedomannya.

Seksi Pelayanan Informasi Publik merupakan seksi yang berada dalam Bidang Informasi, Komunikasi Publik dan Statistik. Dalam implementasi kebijakan keterbukaan informasi publik, petugas pelayanan informasi publik memiliki tanggung jawab untuk melaksanakan dari mulai perencanaan hingga penyebarluasan informasi publik, dan juga layanan hubungan media. Untuk itu, petugas pelayanan informasi adalah implementor dalam menjalankan kebijakan keterbukaan informasi publik pada Dinas Kominfo Pemerintahan Kota Tasikmalaya.

$$
\text { Menurut Awang (2010), }
$$
implementasi kebijakan merupakan sebuah tahap pembuatan keputusan dalam pembentukan sebuah kebijakan. 
Implementasi juga merupakan aktivitas dari kegiatan administrasi pada suatu institusi yang dijalankan oleh unit administratif atau badan publik mulai dari perencanaan hingga evaluasi untuk mencapai tujuan kebijakan yang dapat dirasakan langsung oleh masyarakat.

Dalam implementasi kebijakan, terdapat empat hal penting yang harus diperhatikan, yaitu Komunikasi, Sumber Daya, Disposisi dan juga Struktur Birokrasi (Awang, 2010: 44). Untuk itu, dalam implementasi kebijakan keterbukaan informasi publik yang dilakukan oleh petugas pelayanan informasi Dinas Kominfo Pemerintah Kota Tasikmalaya, harus memperhatikan keempat hal tersebut.

Implementasi

kebijakan

Keterbukaan Informasi Publik yang dilakukan oleh Dinas Kominfo Pemerintahan Kota Tasikmalaya khususnya seksi pelayanan informasi publik dapat dikatakan baik karena berhasil mendapatkan penghargaan pada acara Anugerah Media Humas 2017 peringkat ketiga pada kategori media sosial. Namun, terdapat beberapa beberapa kelemahan. Pertama, faktor komunikasi. Meskipun petugas setiap harinya menyebarluaskan informasi publik pada media baru, tetapi terdapat beberapa informasi yang dianggap kurang jelas sehingga terkadang masyarakat memilih mendatangi langsung kantor kelurahan atau kecamatan untuk mencari informasi publik. Kedua, sumber daya petugas. Ada kekurangan jumlah staf dan masih terdapat fasilitas penunjang yang belum terpenuhi. Staf hanya dua orang petugas tetap yang terus mengupayakan untuk selalu menyebarluaskan informasi publik secara berkala pada media baru. Berikut pembahasan lebih rinci dari faktor-faktor dalam implementasi kebijakan keterbukaan informasi publik yang dijalankan oleh seksi pelayanan informasi publik.

\section{Komunikasi}

Terdapat beberapa komunikasi yang dilakukan dalam implementasi kebijakan keterbukaan informasi publik yang dilakukan oleh seksi pelayanan informasi publik. Pertama, komunikasi yang dilakukan dengan pembuat kebijakan. Bentuk komunikasi yang dijalankan antara pembuat kebijakan dengan petugas sebagai implementor adalah dengan cara dilakukannya sosialisasi pada saat adanya kebijakankebijakan baru yang harus dijalankan oleh implementor. Bentuk komunikasi yang dilakukan dengan sosialisasi dianggap efektif oleh petugas karena petugas secara langsung mendapatkan informasiinformasi langsung dari pembuat kebijakan sehingga dapat meminimalkan terjadinya kesalahan informasi.

Komunikasi juga dilakukan antara petugas dengan masyarakat Kota Tasikmalaya dengan cara menggunakan media yang ada, termasuk media baru seperti media sosial Twitter, Facebook, Instagram @PemkotTasm. Selain itu, media elektronik dan juga media cetak yang bekerja sama dengan media-media lokal Tasikmalaya. Pada media sosial, petugas setiap hari menyebarluaskan informasi publik sehingga pada November 2017 berhasil mendapatkan penghargaan peringkat ke-3 untuk kategori Media Sosial pada acara Anugerah Media Humas 2017.

Pemilihan media didasari beberapa alasan. Salah satu alasannya audiens. Dengan menggunakan media-media tersebut, diharapkan dapat mencapai 
audiens sebanyak-banyaknya, terlebih lagi sekarang masyarakat cenderung menggunakan media sosial dalam kesehariannya. Media luar ruang seperti baliho tidak digunakan oleh petugas karena dianggap kurang efektif.

Dari data yang ditemukan peneliti melalui wawancara dengan beberapa anggota masyarakat Kota Tasikmalaya, masyarakat memang sering memanfaatkan media terlebih media sosial sebagai sarana untuk mencari informasi publik, tetapi masyarakat merasa kurang puas apabila hanya mencari informasi melalui media sosial. Ini karena informasi yang ada pada media sosial atau website hanya informasi secara umum saja. Untuk itu, terkadang, masyarakat tidak mendapat kepuasan apabila hanya mencari informasi melalui media. Oleh karena masyarakat tidak mendapatkan kepuasan dalam pencarian informasi tersebut, penyebarluasan informasi melalui media sosial danggap kurang efektif. Dengan demikian, menurut masyarakat Kota Tasikmalaya, informasi yang dikomunikasikan melalui media sosial masih kurang jelas sehingga, dari sisi faktor komunikasi, memang belum terpenuhi dengan baik dalam implementasi kebijakan KIP.

Selain menggunakan media, petugas juga melakukan komunikasi secara langsung. Komunikasi langsung dilakukan antara petugas dengan petugas kecamatan dan kelurahan yang mengelola KIM (kelompok informasi masyarakat). Petugas menyosialisasikan terkait kebijakan-kebijakan baru yang ada di Kota Tasikmalaya dengan tujuan agar masyarakat mendapatkan kemudahan dalam mendapatkan informasi. Ini memberi solusi yang tepat untuk memberikan kepuasan terhadap masyarakat mengingat masyarakat Kota
Tasikmalaya belum merasakan kepuasan atas informasi yang diperoleh pada media. Selain itu, pada informasi tertentu, petugas juga melakukan komunikasi secara langsung dengan masyarakat apabila masyarakat ingin mendapatkan suatu informasi yang tidak disebarluaskan petugas pada media-media yang telah digunakan. Salah satunya adalah apabila masyarakat meminta informasi terkait anggaran. Dalam hal ini, pemohon informasi harus memberikan data diri yang lengkap dan memaparkan kepada petugas untuk apa informasi tersebut digunakan. Tujuannya agar masyarakat atau pemohon informasi tidak menggunakan informasi untuk hal-hal negatif atau merugikan pihak-pihak tertentu.

Terakhir, komunikasi yang dilakukan antara petugas dengan para wartawan. Di sini, petugas melakukan salah satu tugas dan fungsi Humas yaitu melakukan media relations. Komunikasi dijalin secara personal dengan cara berteman dengan para wartawan sehingga antara kedua belah pihak tersebut sudah terjalin hubungan yang baik sehingga petugas dapat menjadikan media elektronik dan cetak lokal Tasikmalaya sebagai salah satu sarana komunikasi untuk menyebarluaskan informasi publik.

\section{Sumber Daya}

Faktor sumber daya belum sepenuhnya terpenuhi dengan baik dalam implementasi kebijakan keterbukaan informasi publik yang dilakukan oleh seksi pelayanan informasi publik. Jumlah staf yang ada hanya dua. Ini menjadi salah satu hambatan. Petugas sering kali merasa kewalahan karena ketidaksesuaian antara jumlah staf dengan tugas yang harus 

pada Dinas Kominfo Kota Tasikmalaya

dijalankan oleh petugas pelayanan informasi publik.

Permasalahan kekurangan sumber daya manusia dalam mengimplementasikan kebijakan keterbukaan informasi publik Dinas Kominfo Kota Tasikmalaya belum terselesaikan karena penambahan jumlah staf baru akan dilaksanakan apabila ada perekrutan CPNS (calon pegawai negeri sipil) yang akan dilakukan pada 2018. Petugas mengatasi hambatan ini dengan menambah jam kerja. Petugas yang seharusnya bekerja dari pukul 07:30-15:30 terkadang petugas harus pulang melebihi dari jam efektif bekerja. Selain itu, pada beberapa kesempatan, petugas harus pergi ke kantor pada hari Sabtu untuk menyelesaikan beberapa pekerjaan yang belum terselesaikan pada hari efektif bekerja.

Dalam mengimplementasikan kebijakan keterbukaan informasi publik, petugas harus memiliki keahlian, yaitu mampu mengoperasikan website dan juga media sosial. Ini dilakukan untuk menghilangkan hambatan lain dalam menyebarluaskan informasi publik karena media sosial menjadi media komunikasi utama yang digunakan oleh petugas dalam menyebarluaskan informasi publik secara berkala. Dari pengamatan yang dilakukan, terlihat bahwa petugas sudah memiliki keahlian tersebut karena setiap harinya petugas selalu menyebarluaskan informasi publik pada media sosial Twitter dan Facebook.

Ada beberapa peran yang dilakukan oleh Ketua Seksi Pelayanan Informasi Publik. Berikut beberapa peran yang dilakukan oleh petugas dalam mengimplementasikan kebijakan keterbukaan informasi publik. a. Pengumpulan informasi publik.

b. Pembuatan konten yang disesuaikan dengan media yang akan digunakan.

c. Pemilihan media yang tepat.

d. Penyebarluasan informasi publik baik menggunakan media maupun sosialisasi langsung dengan pengelola KIM.

e. Melakukan media relations dengan media lokal Kota Tasikmalaya.

f. Melakukan evaluasi kinerja secara internal untuk mengetahui apa saja kinerja yang harus diperbaiki dan harus ditingkatkan.

Selain permasalahan kurangnya jumlah staf, fasilitas penunjang dalam mengimplementasikan kebijakan keterbukaan infoemasi publik juga belum sepenuhnya memadai. Petugas tidak memiliki kamera profesional sebagai alat dokumentasi sehingga petugas hanya menggunakan kamera handphone saja apabila sedang mendokumentasikan kegiatan-kegiatan yang berlangsung dijajaran Pemerintahan Kota Tasikmalaya. Gedung Dinas Kominfo juga masih bergabung dengan Dinas Perhubungan Kota Tasikmalaya meskipun gedung tersebut cukup memadai, tetapi akan lebih efektif lagi apabila kedua Dinas tersebut bertugas dalam gedung yang berbeda. Fasilitas lainnya seperti printer dan juga komputer sudah trepenuhi dengan cukup dalam menunjang petugs dalam mengimplementasikan kebijakan keterbukaan informasi publik. Pada setiap meja kerja petugas, sudah difasilitasi dengan masing-masing komputer dan juga masing-masing printer.

Secara keseluruhan, faktor sumber daya tidak terpenuhi dengan baik dalam mengimplementasikan kebijakan keterbukaan informasi publik oleh seksi 
pelayanan informasi publik. Ini karena petugas masih kekurangan dalam jumlah staf dan juga fasilitas yang menunjang kinerja mereka. Untuk itu, apabila mengacu pada teori implementasi kebijakan yang dikemukakan oleh Edward maka dalam hal ini implementasi kebijakan belum berjalan dengan baik karena belum terpenuhinya kebutuhankebutuhan sumber daya yang menyebabkan terjadinya hambatan dalam mengimplmentasikan suatu kebijakan tersebut.

\section{Disposisi}

Terdapat beberapa sikap yang dilakukan oleh petugas dalam implementasi kebijakan keterbukaan informasi publik. Pertama, sikap tanggung jawab dengan berupaya menaati peraturan terkait keterbukaan informasi publik. Ini karena dengan menaati peraturan maka kinerja petugas diharapkan akan lebih maksimal. Ini dilakukan dengan sikap terbuka para petugas dalam menerima kritik dan saran yang diajukan oleh masyarakat yang disediakan pada website. Petugas berupaya menjawab pertanyaanpertanyaan yang diajukan oleh masyarakat Kota Tasikmalaya pada akun media sosial $@$ PemkotTsm selama pertanyaanpertanyaan tersebut masih dalam ruang lingkup kinerja dan wewenang petugas dalam menjawabnya.

Sikap tanggung jawab tidak hanya dilakukan dalam pelaksanaan penyebarluasan informasi publik. Evaluasi kinerja juga menjadi salah satu ciri adanya sikap tanggung jawab petugas. Dengan adanya evaluasi, kinerja petugas akan meningkat. Ini karena petugas mengetahui apa saja kinerja yang harus diperbaiki dan apa saja kinerja yang harus ditingkatkan.
Meskipun sejauh ini evaluasi yang dilakukan oleh petugas hanya melibatkan internal saja, dan belum melibatkan pihak eksternal, yaitu masyarakat.

Kerjasama yang dilakukan oleh petugas tidak hanya dengan seksi-seksi dalam Dinas Kominfo dan pengelola KIM saja, tetapi juga melakukan kerjasama dengan Humas (hubungan masyarakat) pemerintahan Kota Tasikmalaya. Bentuk kerja sama yang dilakukan adalah dokumentasi karena pada pemerintahan Kota Tasikmalaya tugas dan fungsi humasnya adalah melakukan dokumentasi terkait dengan kegiatan-kegiatan yang dilakukan pemerintahan Kota Tasikmalaya maupun kegiatan Walikota dan Wakil Walikota Tasikmalaya.

Upaya untuk lebih terbuka dengan masyarakat dan melakukan evaluasi kinerja menjadi beberapa bukti bahwa petugas berupaya untuk mentaati peraturan perundang-undangan terkait dengan keterbukaan informasi publik. Dalam jangka panjang, ini dapat meningkatkan partisipasi masyarakat sesuai dengan salah satu tujuan dari dibentuknya UU No 14/2008 tentang Keterbukaan Informasi Publik.

Dari sikap-sikap implementor dalam mengimplementasikan kebijakan keterbukaan informasi publik, dapat dikatakan baik. Seperti dikemukakan oleh Edward (2003), sikap kecenderungan atau keinginan yang dimiliki implementor dalam menjalankan suatu kebijakan harus mampu menunjang terjadinya implementasi kebijakan yang baik. Sikap berupaya menaati peraturan, saling mendukung antara pihak-pihak yang terkait juga adanya kerjasama yang dilakukan oleh implementor merupakan sikap-sikap yang mampu menunjang 
terjadinya implementasi kebijakan keterbukaan informasi publik menjadi lebih maksimal.

\section{Struktur Birokrasi}

Petugas menjalankan SOP (standard operating procedure) yang sudah dirancang oleh kepala Bidang Informasi, Komunikasi Publik dan Statistik Dinas Kominfo pemerintahan Kota Tasikmalaya. Petugas menjadikan SOP sebagai pedoman pendukung dalam menjalankan kebijakan keterbukaan informasi publik setelah Undang-Undang No 14/2008 tentang Keterbukaan Informasi Publik, Peraturan Komisi Informasi No 1/2010 tentang Standar Layanan Informasi Publik dan Instruksi Presiden No 7/2015 tentang Aksi Pencegahan dan Pemberantasan Korupsi.

Tidak hanya SOP, faktor struktur birokrasi ini ditunjang dengan adanya koordinasi yang dilakukan oleh petugas dalam mengimplementasikan kebijakan keterbukaan informasi publik. Petugas melakukan koordinasi dengan petugas kecamatan dan kelurahan yang mengelola KIM (kelompok informasi masyarakat). Koordinasi dilakukan dengan sosialisasi terkait informasi publik seperti cara pembuatan BPJS, kelangkaan E-KTP dan cara mendapatkan program BPNT (bantuan langsung non tunai).

Tidak hanya sosialisasi, petugas juga berkoordinasi dengan melakukan pelatihan dan pembinaan pada pengelola KIM agar pengelola KIM dapat mengoperasikan media sosial dan juga website sehingga tidak hanya petugas seksi pelayanan informasi publik saja yang menyebarluaskan informasi publik melalui media. Namun, pengelola KIM juga dapat melakukan hal tersebut. Pengelola KIM juga diberikan oleh petugas untuk dapat mengakses website resmi pemerintahan Kota Tasikmalaya sehingga pengelola KIM dapat mengisi kolom berita harian pada website baik berita terkait kecamatan maupun kelurahan yang ada di Kota Tasikmalaya.

Secara keseluruhan, dengan adanya SOP yang dijalankan oleh implementor dan juga adanya koordinasi yang berjalan untuk menunjang implementasi kebijakan keterbukaan informasi publik, faktor struktur birokrasi sudah cukup berjalan dengan baik pada implementasi KIP. Ini selaras dengan pernyataan Edward III (2003) yang menjelaskan bahwa dalam sebuah implementasi kebijakan SOP diperlukan untuk salah satu pedoman dari pelaksanaan suatu kebijakan. Selain itu koordinasi juga diperlukan karena terkadang badan publik mendapatkan tekanan diluar unit-unit birokrasi, untuk itu sehendaknya implementor melakukan koordinasi dengan beberapa pihak yang terkait untuk mengatasi hal tersebut.

\section{PENUTUP}

Berdasarkan temuan penelitian dan juga analisis yang dilakukan dengan menggunakan teori implementasi kebijakan yang melibatkan 4 faktor, yaitu komunikasi, sumber daya, disposisi dan struktur birokrasi. Maka, dapat ditarik kesimpulan sebagai berikut. Pertama, dari sisi komunikasi. Dari hasil temuan dan analisis yang sudah dilakukan oleh peneliti, dapat diketahui bahwa komunikasi antara pembuat kebijakan dengan para implementor sudah berjalan dengan cukup baik, selain itu komunikasi antara implementor dan media lokal di Tasikmalaya juga sudah cukup baik. 
Namun, komunikasi antara implementor dengan publik dalam menyebarluaskan informasi belum sepenuhnya terpenuhi dengan baik. Menurut anggota masyarakat yang menjadi informan penelitian ini, informasi-informasi yang ada di media dianggap kurang memenuhi kebutuhan informasi publik sehingga masyarakat harus mendatangi kantor kecamatan atau kelurahan untuk mendaparkan informasi secara lengkap.

Permasalahan tersebut terselamatkan dengan adanya program KIM (kelompok Informasi Masyarakat) dimana petugas sebagai implementor melakukan komunikasi secara langsung dengan bentuk sosialisasi kepada para pengelola KIM untuk menginformasikan apabila terdapat kebijakan-kebijakan baru, sehingga pengelola KIM ditingkat kecamatan dan kelurahan kota Tasikmalaya dapat memenuhi kebutuhan informasi apabila masyarakat secara langsung mendatangi kantor kecamatan atau kelurahan untuk mencari informasi publik.

Kedua, sumber daya. Faktor sumber daya dalam implementasi kebijakan keterbukaan informasi publik yang dilakukan oleh petugas seksi pelayanan informasi publik belum terpenuhi dengan baik, dari mulai jumlah staf hingga fasilitas yang menunjang dalam kinerja petugas. Terlebih, kekurangan faktor tersebut dapat menimbulkan hambatan seperti data yang sudah dipaparlan sebelumnya oleh peneliti. Meskipun demikian, petugas tetap menjalankan tugasnya dengan maksimal terlihat dari selalu updatenya informasi pada media sosial yang dikelola.
Ketiga, disposisi. Faktor disposisi dalam implementasi kebijakan keterbukaan informasi publik yang dilakukan oleh seksi pelayanan informasi publik sudah cukup terpenuhi dengan baik. Petugas sudah memiliki sikap-sikap yang dapat menunjangn terciptanya implementasi kebijakan yang baik.

Keempat, strukur birokrasi. Adanya SOP dan koordinasi yang dilakukan oleh petugas dalam mengimplemntasikan kebijakan keterbukaan informasi publik sudah cukup memenuhi kebutuhan faktor struktur birokrasi seperti yang dipaparkan oleh Edwards dalam teori Implementasi Kebijakan.

Dari keempat kesimpulan di atas, penelitian ini merekomendasikan sebagai berikut.

Pertama, petugas dapat melakukan evaluasi dengan cara melakukan survey kepuasan masyarakat agar petugas mengetahui apa saja kinerja yang harus ditingkatkan sesuai dengan keinginan masyarakat Kota Tasikmalaya.

Kedua, petugas perlu menyesuaikan informasi yang ditampilkan pada media-media dengan apa yang dibutuhkan oleh masyarakat. Agar masyarakat tidak hanya memanfaatkan petugas kecamatan atau kelurahan saja dalam memenuhi kebutuhan informasi publik.

Ketiga, petugas perlu segera memenuhi kapasitas sumber daya yang kurang memadai agar dapat menunjang kinerja yang lebih maksimal. 


\section{DAFTAR PUSTAKA}

Aritonang (2011). "Kebijakan Komunikasi di Indonesia: Gambaran Implementasi UU No.14/2008 tentang Keterbukaan Informasi Publik” Jurnal Komunikasi, Volume 1. (2011) hal. 261

Awang, Azam. (2010). Implementasi Pemberdayaan Pemerintah Desa. Yogyakarta: Pustaka Pelajar

Bungin, Burhan. (2005) Metode Penelitian Kuantitatif. Jakarta: Kencana Prenada Media Group

Edwards, George. (2003). Implementasi Kebijakan Publik. Yogyakarta: Lukman Offset.

Kamaliah, Khairunnisa (2015). "Implementasi Undang-Undang nomor 14 tahun 2008 Tentang Keterbukaan Informasi Publik di Badan Perencanaan Pembangunan Pemerintah Kota Samarinda”. eJournal Ilmu Pemerintahan Volume 3. (2015) hal 10-11

Kriyantono, Rachmat. (2010). Teknik Praktis Riset Komunikasi, Jakarta: Prenada Media Group

Moleong, Lexy J. (2010). Metodologi Penelitian Kualitatif. Bandung: PT Remaja Rosdakarya Offset.

PPID "Data tentang Badan Publik" https://ppid.kominfo.go.id/badanpublik (diakses pada Februari 2018)
Prabowo, Rizki Dwi (2014). "Implementasi Undang-Undang Keterbukaan Informasi Publik dalam Upaya mencipatakan Good Governance (Kajian Tiga Badan Publik: Bappeda, DPKAD dan Dinas Pendidikan Kota Semarang)" . Jurnal Ilmu Sosial dan Ilmu Politik. Volume 3 (2014) hal 26-29.

Sastro, Dhoho A, et.al. (2010). Mengenal Undang-Undang Keterbukaan Informas Publik. Jakarta: Lembaga Bantuan Hukum

Sedarmayanti. (2004). Good Governance (Kepemerintahan yang Baik). Bandung: Mandar Maju

Setiaman, Agus, Dadang Sugiana dan Jimi Narotama (2013). "Analisis Kritis Implementasi Kebijakan Keterbukaan Informasi Publik di Pemerintah Kota Bandung kepada Warga Kota. Bandung”. Jurnal Ilmu Komunikasi Volume. 1. (Desember, 2013), hal 9-10.

Thaib, Dahlan. (1998). Implementasi Sistem Ketatanegaraan Menurut UUD 1945. Yogyakarta: Liberty Yogyakarta. 
Jurnal komunikasi, Volume 12, Nomor 2, April 2018 